\title{
Genetic diversity and population structure of Brazilian native bovine breeds
}

Germana Maria Serrano(1), Andréa Alves do Egito(2), Concepta McManus(1) and Arthur da Silva Mariante ${ }^{(2)}$

(1) Universidade de Brasília, Fac. de Agronomia e Medicina Veterinária, Caixa Postal 04508, CEP 70910-900 Brasília, DF. E-mail: gmsserrano@yahoo.com.br, concepta@unb.br (2)Embrapa Recursos Genéticos e Biotecnologia, Caixa Postal 02372, CEP 70770-900 Brasília, DF. E-mail: egito@cenargen.embrapa.br, mariante@cenargen.embrapa.br

Abstract - Conservation and improvement strategies should be based on the association between genetic and phenotypic characteristics. The objective of this work was to characterize five native Brazilian cattle breeds (Caracu, Crioulo Lageano, Curraleiro, National Polled and Pantaneiro) and two commercial breeds (Holstein and Nellore) using RAPD technique to estimate genetic distances and variability between and within breeds. Genetic relationships were investigated using 22 primers which generated 122 polymorphic bands. Analysis of molecular variance indicated that most of the genetic variation lay among individuals within populations. The genetic variabilities between pairs of breeds were statistically significant. The smallest genetic divergence was between Crioulo Lageano and Curraleiro. The National Polled, although historically considered to be of Bos taurus aquitanicus origin, similar to the Caracu, was grouped together with the other breeds of Bos taurus ibericus origin. Generally, the individual breeds formed distinct clusters except the National Polled. The RAPD technique was capable to distinguish genetically between the breeds studied; the Caracu, Crioulo Lageano, Curraleiro and Pantaneiro may be considered distinct genetic entities thereby proving the uniqueness of the populations; the National Polled has not been able to re-establish itself after its decline in the 1950s, thereby losing its genetic identity.

Index terms: animal conservation, cattle, genetic characterization, RAPD.

\section{Diversidade genética e estrutura de população de bovinos nativos}

Resumo - Estratégias para conservação e melhoramento animal devem ser baseadas na associação de características fenotípicas e genéticas. O objetivo deste trabalho foi caracterizar cinco raças nativas brasileiras (Caracu, Crioulo Lageano, Curraleiro, Mocho Nacional e Pantaneiro) e duas comerciais (Holandês e Nelore) pela técnica de RAPD para estimar a distância genética e a variabilidade genética entre e dentro das raças. As relações genéticas foram investigadas utilizando-se 22 primers, que geraram 122 bandas polimórficas. A análise de variância molecular revelou que a maior parte da variabilidade genética total ocorreu em virtude das diferenças de indivíduos dentro das populações. Na comparação da variabilidade genética entre os pares de raças, observou-se que todos os valores obtidos foram estatisticamente significativos. A menor divergência genética foi observada entre Crioulo Lageano e Curraleiro. A raça Mocho Nacional, apesar de historicamente ser considerada de origem Bos taurus aquitanicus, mesma origem da raça Caracu, agrupou-se com as demais raças nativas consideradas de origem Bos taurus ibericus. De modo geral, as raças estudadas se agruparam em clusters distintos, com exceção da Mocho Nacional. A técnica de RAPD foi capaz de distinguir geneticamente as raças estudadas; Caracu, Crioulo Lageano, Curraleiro e Pantaneiro podem ser consideradas entidades genéticas distintas, comprovando assim, a unicidade de suas populações; a Mocho Nacional não conseguiu se restabelecer, após seu declínio na década de 50, perdendo, sua identidade genética.

Termos para indexação: conservação animal, bovino, caracterização genética, RAPD.

\section{Introduction}

Contrary to phenotypic characterization, genetic characterization is free of environmental influences, which means greater accuracy in the data generated. This is fundamental when decisions have to be made in conservation programs or on the utilization of animal genetic resources. Thus, techniques used in the analysis of genetic variability are essential ingredients for conservation programs and in making rational breeding decisions (Egito et al., 1999). 
In Brazil, few studies can be found on the characterization of native/naturalized cattle breeds. A study of these breeds could help in rational development of future breeding programs, as well as in the preservation and conservation of these germplasm. Gains in economic efficiency, which could result from the use of this genetic material, may be greater than the cost of conservation of these animals. Many breeds, which were once economically important, are now rare but may have traits with economic potential (Hall \& Bradley, 1995).

Brazilian bovine breeds were developed from breeds brought by the colonizers soon after the discovery of Brazil. Since then those breeds underwent natura selection in specific environments, with adaptation of traits suited to those conditions (Mariante \& Cavalcante, 2000).

Portuguese purebred cattle belonged to one of three main bloodlines: Batavian (Bos taurus batavicus), represented by the Barrosa and Turino breeds Aquitanian (Bos taurus aquitanicus), represented by the Galega, Arouquesa, Alentejana, Mertolenga, Algarvia, and Minhota breeds; and Iberian (Bos taurus ibericus), represented by the Mirandesa and Brava breeds.

According to Athanassof (1957), the Brazilian cattle breeds that belong to the Bos taurus ibericus are smal to medium sized; those of the Bos taurus aquitanicus are above average size, while those that belong to the Bos taurus batavicus are, generally, crossbreds with dual purpose breeds and present size below average. Based on historic information, Primo (1993) stated that Curraleiro, Crioulo Lageano and Pantaneiro breeds have their origin in breeds from the Bos taurus ibericus type, while the Caracu and National Polled breeds belong to the Bos taurus aquitanicus type.

Because of the importation, at the begining of the $20^{\text {th }}$ century, of some exotic breeds, especially zebu, native breeds were gradually substituted. Thus, today the greater part of the native breeds are threatened with extinction, making the study of the genetic variability of these breeds of prime importance (Egito et al., 1999). Although the exotic breeds are considered more productive, they lack adaptive, disease and parasite resistance traits found in the native breeds.

Modern strategies for bovine genetic improvemen and conservation require sets of molecular markers that characterize different populations (Hetzel \& Drinkwater, 1992). An efficient and low-cost technique for detecting DNA polymorphisms uses PCR and primers of arbitrary sequence to amplify genomic DNA (Williams et al.,
1990), in the Random Amplified Polymorphic DNA (RAPD) assay.

This technique is widely used to help in the choice of strategies for preservation of species and animals threatened with extinction (Apostolidis et al., 2001).

However, only few studies have been conducted with this technique on bovine germplasm, focusing on subspecies or breed identification and identification of chromosome markers (Teale et al., 1995).

The objective of this work was to characterize five native Brazilian cattle breeds and two commercial breeds using RAPD technique to estimate genetic distances and variability between and within breeds.

\section{Material and Methods}

\section{Animals}

Five naturalized Brazilian cattle breeds were studied. These included the Pantaneiro (PAN) from the Pantanal region, South Western Brazil; Crioulo Lageano (CL) from Santa Catarina State, Southern Brazil; Curraleiro (CU) from the Northeast and Central West States; National Polled (MN) from Minas Gerais State, Southeastern Brazil; and Caracu (CA) from Central West and Southern Brazil. Two established and well defined breeds in Brazil were included: the HolsteinFriesian (HOL) (Bos taurus) as a control group, and the Nellore (NEL) (Bos indicus) as an outgroup.

To obtain a representative sample size for each native breed, depending on its occurrence, animals from different herds and regions of Brazil were collected (Table 1). The total sample size was 335 individuals, which included 48 animals of each breed (the number recommended by FAO for characterization studies), except for the National Polled for which only 47 samples were available.

\section{DNA extraction and amplification}

Genomic DNA was obtained from blood samples or frozen semen samples provided by private breeders, Conservation Nuclei and Animal Germplasm Bank of Embrapa Recursos Genéticos e Biotecnologia. Semen DNA extraction was based on a phenol protocol described by Egito (1995) and blood DNA extraction was based on Miller et al. (1988) with slight modifications (non-organic protocol).

A total of 120 arbitrary primers (Operon Technologies Inc., Alameda, Calif.: A, B, E, J, K and AB) was screened using one sample of each breed. A total of 22 primers was selected and used to amplify DNA from all 
individuals (OPA 2, OPA 4, OPA 8, OPA 9, OPA 11, OPA 12 , OPA 15 , OPA 16 , OPA 17 , OPA 19 , OPB 1 , OPB 8 , OPB 12 , OPE 12 , OPJ 7 , OPJ 8 , OPJ 12 , OPJ 14, OPJ 17, OPAB 1, OPAB 4 and OPAB 5).

Amplification reactions were performed in $50 \mathrm{mM}$ $\mathrm{KCl}, 20 \mathrm{mM}$ Tris- $\mathrm{HCl}$ ( $\mathrm{pH} 8.4$ ), $2.5 \mathrm{mM} \mathrm{MgCl}$, $200 \mathrm{mM}$ of each dNTP, $0.4 \mu \mathrm{M}$ primer, $9 \mathrm{ng}$ template DNA, $8 \%$ of BSA $(2.5 \mathrm{mg} / \mathrm{mL})$ and 1.5 UI Taq DNA polymerase in a final volume of $13 \mu \mathrm{L}$. DNA amplification was performed in a thermal cycler programmed as follows: $94^{\circ} \mathrm{C}$ for $5 \mathrm{~min}$ followed by 40 cycles consisting of $94^{\circ} \mathrm{C}$ for $1 \mathrm{~min}, 36^{\circ} \mathrm{C}$ for $1 \mathrm{~min}$ $72^{\circ} \mathrm{C}$ for $2 \mathrm{~min}$. A final extension at $72^{\circ} \mathrm{C}$ was carried out for $7 \mathrm{~min}$ followed by cooling at $4^{\circ} \mathrm{C}$. PCR products were separated by electrophoresis in $1.4 \%$ agarose gels in $1 \mathrm{x}$ TBE, and were stained with ethidium bromide $(0.6 \mu \mathrm{g} / \mathrm{mL})$ and observed under UV light.

\section{Data scoring and analysis}

Although a large number of fragments were generated from each primer, only clearly distinguishable and reproducible polymorphic bands were selected for analysis. Sex specific or individual bands were excluded. Fragment data were entered in a computer file as a binary matrix: "0" coded for absence and "1" for presence of a band.

Table 1. Estimated population size of Brazilian naturalized cattle breeds, herds collected for genetic characterization and number of analyzed animals, by breed and herd.

\begin{tabular}{|c|c|c|}
\hline Breed & $\begin{array}{l}\text { Estimated } \\
\text { pop. size }\end{array}$ & $\begin{array}{l}\text { Origin of the animals sampled for genetic } \\
\text { characterization (number of animals analyzed) }\end{array}$ \\
\hline Caracu & 30,000 & $\begin{array}{l}\text { Chiqueirão Farm - Poços de Caldas, MG (17) } \\
\text { São Miguel Farm - Conceição da Aparecida, MG (5) } \\
\text { São Francisco Farm - Bambuí, MG (8) } \\
\text { Belém Farm - Passos, MG (6) } \\
\text { São Bento Farm - São Luiz dos Montes Belos, GO (5) } \\
\text { Recreio Farm - São Sebastião da Gra, SP (5) } \\
\text { Douradinha Farm - Uberlândia, MG (2) }\end{array}$ \\
\hline $\begin{array}{l}\text { Crioulo } \\
\text { Lageano }\end{array}$ & $100-1,000$ & $\begin{array}{l}\text { Canoas Farm, Crioulo Lageano Nuclei - Lages, } \\
\text { SC (48) }\end{array}$ \\
\hline & o 500-1,000 & $\begin{array}{l}0 \text { Curraleiro Nucleus - Embrapa Meio Norte PI (12) } \\
\text { Salto da Divisa, MG (7) } \\
\text { Lagoa Branca Farm - Mara Rosa, GO }(9)^{(1)} \\
\text { Santa Mônica Farm - Mara Rosa, GO }(20)^{(2)} \\
\end{array}$ \\
\hline $\begin{array}{l}\text { National } \\
\text { Polled }\end{array}$ & 400 & $\begin{array}{l}\text { Brazilian Animal Gene Bank (Embrapa Genetic } \\
\text { Resources and Biotechnology) - Brasilia, DF (13) } \\
\text { Três Barras Farm - Uberaba, MG (34) }\end{array}$ \\
\hline Pantanei & 8,300 & $\begin{array}{l}\text { Nhumirim Experimental Farm - Embrapa Pantanal, } \\
\text { Corumbá, MS (48) }\end{array}$ \\
\hline
\end{tabular}

Data analyses were conducted using NTSYS-pc, version 2.0. Similarities between individuals were estimated using Jaccard coefficients of similarity (Sneath $\&$ Sokal, 1973) and the resulting pairwise similarities were expressed as distance matrices.

The genetic distances between breeds were calculated using the POPGENE program (Population Genetic Analysis) version 1.31 (Yeh et al., 1999). This program establishes standardized genetic distance matrices (Nei, 1972) and matrices of genetic distances corrected for small samples (Nei, 1978). The method proposed by Nei (1972) is one of the most used to obtain genetic distances between populations (Lynch \& Milligan, 1994) and its use is recommended with RAPD data (Apostolidis et al., 2001). All cluster analyses done in this work were conducted using UPGMA and the resulting clusters were expressed as dendrograms. The bootstrap analysis was conducted using the TFPGA program (Tools for Population Genetics Analyses, version 1.3) (Miller, 1997). The POPGENE program also generated gene diversity indices (h) for each breed based on Nei (1973). According to Weir (1996) this is the most adequate method to study unique populations.

The analysis of molecular variance (AMOVA) (Excoffier et al., 1992) was used to separate the variance between and within populations using the ARLEQUIN program (Schneider et al., 2000). Although this test was not originally designed for analysis of RAPD data, it has been used in other similar studies (Tansley \& Brown, 2000).

\section{Results and Discussion}

\section{Genetic structure of the breeds}

When all breeds were used, the greater part of total genetic variability $(70.04 \%)$ was due to differences between individuals within populations while the remaining $29.96 \%$ was due to differences between breeds (Table 2 ). When only the native breeds were used, the within breed variability increased to $83.73 \%$. Therefore, the genetic variability between the native breeds was much lower than between all breeds, confirming their more restricted genetic base. These results agree with other studies using genetic markers (Tansley \& Brown, 2000), where the greater part of genetic variance is due to differences between individuals within breeds.

The gene diversity index was calculated for all breeds, considering them as unique populations (Table 3). This 
analysis was based on the mean allelic frequency of the 122 RAPD markers, which varied from $300 \mathrm{bp}$ to 2,000 bp. The Caracu presented lowest gene diversity (0.1904) when compared to the other native breeds. These results agree with Poli (1985) who, using blood factor phenograms, also observed lower gene diversity in this breed. Until the year 2000 this was the only native breed that had a Breeder's Association, which may explain these observations.

Estimation of genetic distance

The estimates of genetic distances between the breeds were calculated to help in the study of genetic

Table 2. Analysis of molecular variance (AMOVA) of the seven populations (breeds) studied, using 122 RAPD markers ${ }^{(1)}$.

\begin{tabular}{|c|c|c|c|c|c|}
\hline Source of variation & $\mathrm{DF}$ & SS & MS & $\mathrm{VC}$ & \% Total \\
\hline Between breeds & 6 & 1709.453 & 284.901 & 5.676 & $29.96^{*}$ \\
\hline Within breeds & 328 & 4352.064 & 13.26849 & 13.268 & $70.04^{\mathrm{ns}}$ \\
\hline Between native breeds & & 557.652 & & 2.633 & $16.27^{*}$ \\
\hline Within native breeds & 234 & 3170.172 & 12.54775 & 13.548 & $83.73^{\text {ns }}$ \\
\hline \multicolumn{6}{|c|}{$\begin{array}{l}\text { (1)DF: degrees of freedom; SS: sum of squares; MS: mean square } \\
\text { VC: variance components. }{ }^{(2)} \text { Only native breeds were considered } \\
\text { ns No-significant. *Significant at } 5 \% \text { level of probability. }\end{array}$} \\
\hline \multicolumn{6}{|c|}{$\begin{array}{l}\text { Table 3. Nei's (1973) gene diversity index (h) of breeds, using } \\
\text { the POPGENE program, considering them as unique } \\
\text { populations. }\end{array}$} \\
\hline \multicolumn{4}{|l|}{ Breed } & \multicolumn{2}{|r|}{ (h) } \\
\hline & \multicolumn{2}{|c|}{0.1904} \\
\hline \multirow{2}{*}{\multicolumn{4}{|c|}{$\begin{array}{l}\text { Crioulo Lageano } \\
\text { Curraleiro }\end{array}$}} & \multicolumn{2}{|c|}{0.2409} \\
\hline & & & & \multicolumn{2}{|c|}{0.2492} \\
\hline \multicolumn{4}{|l|}{ Holstein Friesian } & \multicolumn{2}{|c|}{0.1342} \\
\hline \multicolumn{4}{|l|}{ National Polled } & \multicolumn{2}{|c|}{0.2449} \\
\hline & \multicolumn{2}{|c|}{0.2524} \\
\hline \multicolumn{4}{|l|}{$\begin{array}{l}\text { Nellore } \\
\text { Pantaneiro }\end{array}$} & & .2464 \\
\hline
\end{tabular}

relationships and genetic divergence between pairs of populations for standard genetic distances (Dp) (Nei, 1972) and those corrected for small populations (Dc) (Nei, 1978) (Table 4).

Native breeds closest to the Nellore were the Crioulo Lageano ( $\mathrm{Dc}=0.2536)$ and Pantaneiro $(\mathrm{Dc}=0.2550)$ and the furtherst was the Caracu (Dc=0.3879). The first observation may be explained by the historical data from the breed in which, in the past, Nellore or crossbred Nellore bulls were used. The lowest divergence was observed between the Crioulo Lageano and Curraleiro breeds $(\mathrm{Dc}=0.0424)$. The phenotypes of these breeds are different and they inhabit distinct regions of Brazil (extreme south and central west, respectively). Poli (1985) found the smallest difference between Crioulo Lageano and Pantaneiro breeds. The difference found here might be due to the different techniques used. Poli (1985) compared the breeds based on three blood group frequencies and the mean number of blood factors per animal in each group. In spite of these different results, Primo (1993) stated that the probable ancestor of the Curraleiro, Crioulo Lageano and Pantaneiro breeds was the Bos taurus ibericus, while the Caracu and National Polled had the Bos taurus aquitanicus as their common ancestor. The mean Dp and Dc values between native breeds were 0.06887 and 0.06466 , respectively.

The dendrogram of the genetic distance matrix generated by the UPGMA method (Nei, 1978) as well as bootstrapping proportions are shown in Figure 1. The Bos taurus breeds are grouped in one cluster separated from the Nellore (Bos indicus). The native breeds are in a cluster separated from the Holstein-Friesian, reconfirming the hypothesis that they share a common ancestor. Within the native breed cluster, the smallest genetic divergence was shown between the Crioulo Lageano and Curraleiro breeds and the National Polled

Table 4. Genetic distances between seven cattle breeds estimated using Nei $(1972,1978)$ methods, from RAPD data, using the POPGENE program. The standard genetic distances (Nei, 1972) are below the diagonal, and corrected distances (Nei, 1978), above the diagonal.

\begin{tabular}{lccccccc}
\hline Cattle breed & Caracu & Crioulo Lageano & Curraleiro & Holstein Friesian & National Polled & Nellore & Pantaneiro \\
\hline Caracu & - & 0.0813 & 0.0650 & 0.0930 & 0.0847 & 0.3879 & 0.0951 \\
Crioulo Lageano & 0.0842 & - & 0.0424 & 0.0857 & 0.0464 & 0.2536 & 0.0599 \\
Curraleiro & 0.0680 & 0.0458 & - & 0.0940 & 0.0566 & 0.2971 & 0.0510 \\
Holstein Friesian & 0.0950 & 0.0883 & 0.0965 & - & 0.0766 & 0.4234 & 0.1108 \\
National Polled & 0.0877 & 0.0499 & 0.0600 & 0.0801 & - & 0.2585 & 0.0738 \\
Nellore & 0.3909 & 0.2571 & 0.3006 & 0.4260 & 0.2621 & - & 0.2550 \\
Pantaneiro & 0.0981 & 0.0633 & 0.0544 & 0.1133 & 0.0773 & 0.2590 & - \\
\hline
\end{tabular}


was grouped with animals considered of Bos taurus ibericus origin (Curraleiro, Crioulo Lageano and Pantaneiro). According to Athanassof (1957), these animals were small to medium sized. This puts the affirmation of the common ancestor of the Caracu and National Polled as being the Bos taurus aquitanicus (large framed animals) in question.

\section{Genetic similarity}

The genetic similarity indices were used to generate, using UPGMA, a dendrogram based on all the samples used. Jaccard similarity coefficients were calculated from the binary data matrix from the 122 markers obtained by RAPD (Figure 2).

The Caracu has the best genetic standard defined within the native breeds, as its animals are all within the same cluster. This may be due to the selection that has been carried out, as well as the work carried out by the Breeder's Association to maintain this breed. The Nellore and Holstein Friesians also are grouped in single clusters.

Generally, the native breeds are grouped in clusters, except for the National Polled, in which 29 animals are grouped beside the Holstein Friesian cluster and the rest are distributed within the clusters of the other breeds. This may reflect the genetic dilution process to which this breed has been submitted over the last decades. The National Polled was considered practically extinct in the 1970s and various breeders crossed the remaining animals with other breeds, which justifies their distribution throughout the dendrogram.

Its phenotypic similarity to the Caracu led many technicians and breeders to believe that this was a polled

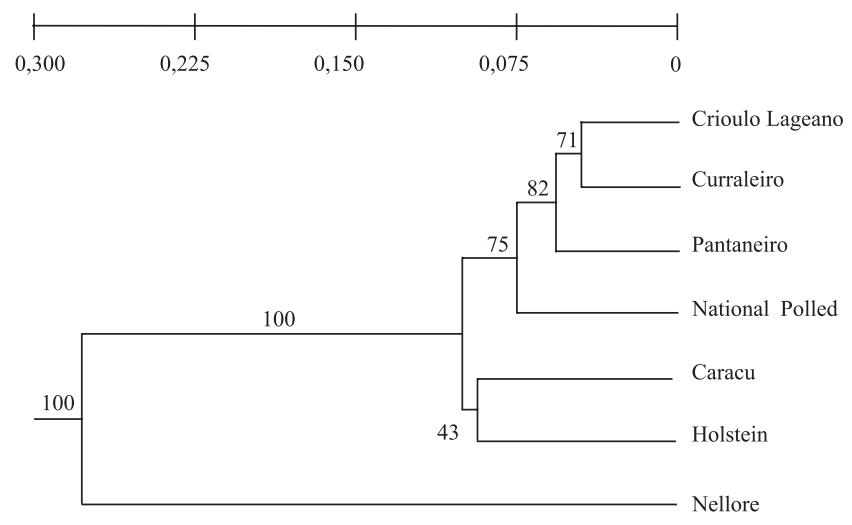

Figure 1. Dendrogram generated by the UPGMA method for Nei (1978) genetic distance using TFPGA program. The confidence value of each node was estimated from 10.000 permutations.

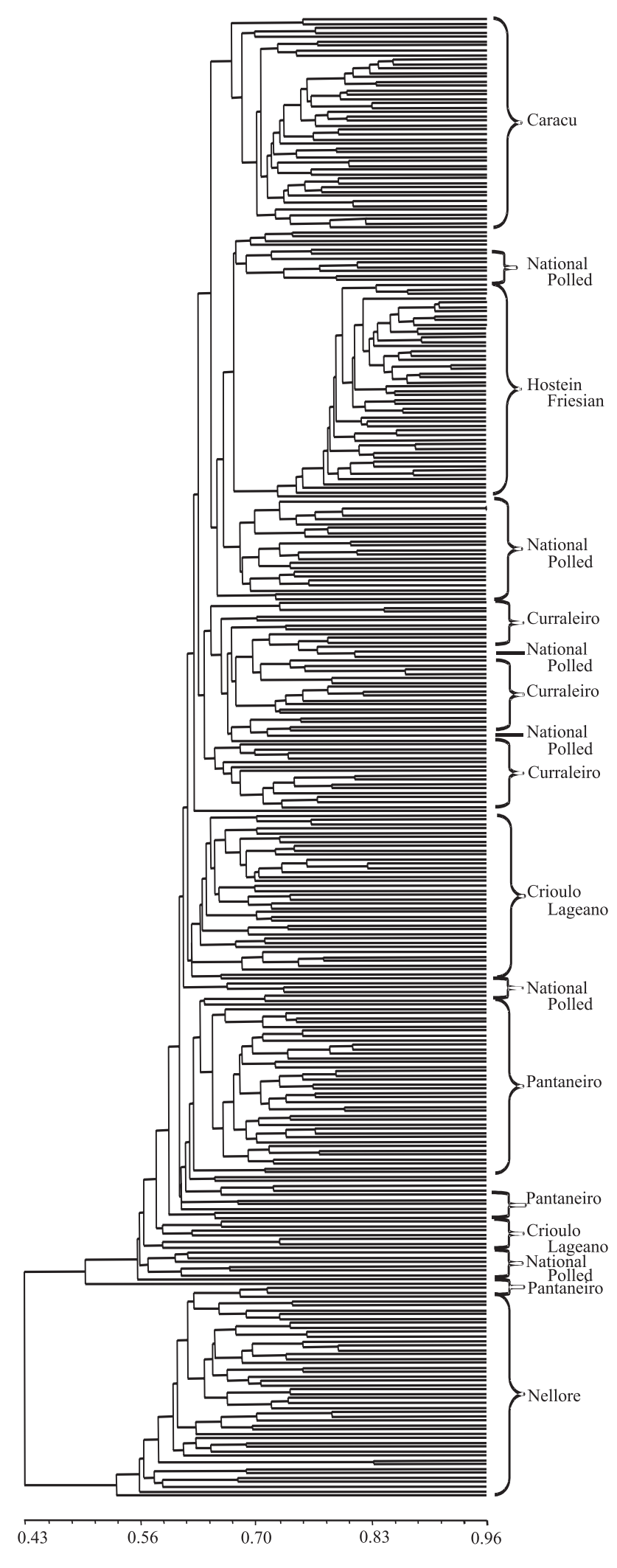

Figure 2. Individual dendrogram constructed from Jaccard similarity coefficient using NTSYS-pc program. 
version of the Caracu, and the Caracu Breeder's Association registers it as "Caracu, polled variety". This study shows that, probably, these breeds were not genetically similar in the past. By means of the breeding strategies being carried out on this breed, the tendency is that they become genetically similar to the Caracu, and the latter will absorb the National Polled genes.

Various small clusters were formed near the Nellore group, which include Pantaneiro, Crioulo Lageano and National Polled animals separated from the general Bos taurus cluster. These may represent miscegenation of these animals due to crossbreeding with zebu breeds. It is well known that since the introduction of zebu animals in Brazil, these were widely used in grading up crossbreeding schemes with native breeds (Mariante, 1993). Lara (1998) found a considerable contribution of zebu genes in a population of Pantaneiro cattle from the Poconé region of Mato Grosso State, which therefore was grouped together with the Bos indicus cluster. The animals from the Pantanal Conservation Nucleus in Corumbá, Mato Grosso do Sul State, grouped with the Bos taurus cluster. The Crioulo Lageano nucleus, according to information from the breeder, underwent some introduction of Nellore genes for a short period in the 1980s.

The Brazilian native breeds, with the exception of the Caracu, lack standardization and control. Crossbreds of these breeds with zebu or other commercial breeds, or even with animals that are phenotypically but not genetically similar, should be identified and excluded from conservation programs.

\section{Conclusions}

1. The native Caracu, Crioulo Lageano, Curraleiro and Pantaneiro breeds can be considered distinct genetic entities, thereby proving the uniqueness of their populations and the importance of their conservation.

2. Among the native breeds, Caracu has the best genetic standard, showing the importance of the Herdbook and Breeder's Association for maintenance and conservation of the breed, while the National Polled probably has not managed to re-establish itself after its decline in the 1950s, loosing its genetic identity.

3. Zebu genes have been introduced into some of the animals of the native breeds, especially Crioulo Lageano, National Polled and Pantaneiro. Control of crossbreeding is fundamental if the preservation of native breeds, threatened with extinction, is to be successful.

\section{Acknowledgements}

To the private breeders and those responsible for the conservation nuclei; to Embrapa and UnB for the financial support; to Capes for the scholarship.

\section{References}

APOSTOLIDIS, A.P.; MAMURIS, Z.; KARKAVELIA, E.; ALIFAKIOTIS, T. Comparison of Greek breeds of horses using RAPD markers. Journal of Animal Breeding and Genetics, v.118, p.47-56, 2001.

ATHANASSOF, N. Manual do criador de bovinos. 6.ed. São Paulo: Melhoramentos, 1957. 818p.

EGITO, A.A. Uso de marcadores RAPD na identificação e caracterização genética de raças bovinas existentes no Brasil. caracterização genética de raças bovinas existentes no Brasil.
1995. 95p. Dissertação (Mestrado) - Universidade de São Paulo, Ribeirão Preto.

EGITO, A.A : ALBUQUERQUE, M.S ; MARIANTE, A da S. Situação atual da caracterização genética animal na Embrapa Recursos Genéticos e Biotecnologia. In: SIMPÓSIO DE RECURSOS GENÉTICOS PARA A AMÉRICA LATINA E CARIBE SIRGEALC, 2., 1999, Brasília. Anais. Brasília: Embrapa-Cenargen. 1999. 5p. Mesaredonda/mes010.pdf. CD-ROM.

EXCOFFIER, L.; SMOUSE, P.E.; QUATTRO, J.M. Analysis of molecular variance inferred from metric distances among DNA haplotypes: application to human mitochondrial DNA restriction data. Genetics, v.131, p.479-491, 1992.

HALL, S.J.G.; BRADLEY, D.G. Conserving livestock breed biodiversity. Trends in Ecology and Evolution, v.10, p.267-270, 1995.

HETZEL, D.J.S.; DRINKWATER, R.D. The use of DNA technologies for the conservation and improvement of animal genetic resources. In: HODGES, J. The management of global animal genetic resources: proceedings of a FAO expert consultation. Rome: FAO, 1992. 309p.

LARA, M.A.C. Variabilidade genética em bovinos e bubalinos através de polimorfismos protéicos: análise populacional e suas implicações no melhoramento. 1998. 215p. Tese (Doutorado) Faculdade de Medicina de Ribeirão Preto, Ribeirão Preto.

LYNCH M.; MILLIGAN, B.G. Analysis of population genetic structure with RAPD markers. Molecular Ecology, v.3, p.91-99, 1994

MARIANTE, A. da S. Conservação de recursos genéticos animais: uma questão de bom senso. In: REUNIÃ̃O ANUAL DA SOCIEDADE BRASILEIRA DE ZOOTECNIA, 1993, Rio de SOCIEDADE BRASILEIRA DE ZOOTECNIA, 1993, Rio de
Janeiro. Anais. Rio de Janeiro: Sociedade Brasileira de Zootecnia, 1993. p.16-23.

MARIANTE, A. da S.; CAVAlCANTE, N. Animais do descobrimento: raças domésticas da história do Brasil. Brasília: Embrapa-Cenargen, 2000. 232p.

MILLER, M.P. Tools for population genetics analyses (TFPGA) ver. 1.3: a Windows program for the analysis of allozyme and ver. 1.3: a Windows program for the analysis of allozyme and
molecular population genetic data. Flagstaff: Northen Arizona University, 1997. 33p. 
MILLER, S.A.; DYKES, D.D.; POLESKY, H.F. A simple salting out procedure for extracting DNA from human nucleated cells. Nucleic Acids Research, v.16, p.1215, 1988

NEI, M. Analysis of gene diversity in subdivided populations. Proceedings of the National Academy of Sciences of United States of America, v.70, p.3321-3323, 1973.

NEI, M. Estimation of average heterozygosity and genetic distance from a small number of individuals. Genetics, v.89, p.583-590, 1978

NEI, M. Genetic distance between populations. American Naturalist, v.106, p.238-292, 1972.

POLI, M.A. Polimorfismo inmunogenéticos: su empleo en conservacion de germoplasma animal. Brasília: Embrapa-Cenargen, 1985. 50p. Convênio Embrapa-INTA. 08/10-15/12: informe final.

PRIMO, A.T. Os bovinos ibéricos nas Américas. In: REUNIÃO ANUAL DA SOCIEDADE BRASILEIRA DE ZOOTECNIA, 1993, Rio de Janeiro. Anais. Rio de Janeiro: Sociedade Brasileira de Zootecnia, 1993, p.183-199.

SCHNEIDER, S.; ROESSLI, D.; EXCOFFIER, L. Arlequin ver 2000: a software for population genetics data analysis. Geneva: University of Geneva, 2000.111p.
SNEATH, P.H.A.; SOKAL, R.R. Numerical taxonomy: the principles and practice of numerical classification. San Francisco: W.H. Freeman, 1973. 573p.

TANSLEY, S.A.; BROWN, C.R. RAPD variation in the rare and endangered (Proteaceae): implications for their conservation. Biological Conservation, v.95, p.39-48, 2000

TEALE, A.J.; WAMBUGU, J.; GWASIKA, P.S.; STRANZINGER, G.; BRADLEY, D.; KEMP, S.J. A polymorphism in randomly amplified DNA that differentiates the Y chromosomes of Bos indicus and Bos taurus. Animal Genetics, v.26, p.243-248, 1995.

WEIR, B.S. Genetic data analysis II: methods for discrete population genetic data. Sunderland: Sinauer Associates, 1996. 445p. WILLIAMS, J.G.K.; KUBELIK, A.R.; LIVAK, K.J.; RAFALSKI, J.A.; TINGEY, S.V. DNA polymorphisms amplified by arbitrary primers are useful as genetics markers. Nucleic Acids Research, v. 18, p.6531-6535, 1990 .

YEH, F.C.; YANG, R.; BOYLE, T. POPGENE: Microsoft Windowbased freeware for population genetic analysis: version 1.3: manual. Edmonton: University of Alberta, 1999. 29p.

Received on October 24, 2003 and accepted on March 15, 2004 